\title{
Structured assessment and followup for patients with hereditary kidney tumour syndromes
}

\author{
Jean-Baptiste Lattouf, MD; Stephen E. Pautler, MD; ${ }^{2}$ M. Neil Reaume, MD; Raymond H. Kim, MD; \\ Melanie Care, MD; Jane Green, MD, ${ }^{6}$ Alan So, MD; Philippe D. Violette, MD, Issam Saliba, MD; ${ }^{9}$ \\ Philippe Major, MD; ${ }^{10}$ Shane Silver, MD;11 Richard Leicht, MD;12 Joan Basiuk, MD; ${ }^{13}$ Simon Tanguay, MD;14 \\ Michael A.S. Jewett, MD, ${ }^{15}$ Darrel Drachenberg, MD, ${ }^{16}$ for the Kidney Cancer Research Network of Canada
}

'Division of Urology, Department of Surgery, University of Montreal Hospital Centre, Montreal, QC, Canada; 2Divisions of Urology and Surgical Oncology, Departments of Surgery and Oncology, Western University, London, ON, Canada; ${ }^{3}$ Division of Medical Oncology, The Ottawa Hospital Cancer Centre, University of Ottawa, Ottawa, ON, Canada; ${ }^{4}$ Division of Medical Oncology, Department of Medicine, Princess Margaret Cancer Centre, University Health Network, University of Toronto, Toronto, ON, Canada; ${ }^{5}$ Fred A. Litwin Family Centre in Genetic Medicine, University Health Network \& Mount Sinai Hospital, Toronto, ON, Canada; 'Disciplines of Genetics and Medicine, Faculty of Medicine, Memorial University of Newfoundland, St. John's, NL, Canada; ${ }^{7}$ Department of Urologic Sciences, Faculty of Medicine, Vancouver General Hospital and University of British Columbia, Vancouver, BC, Canada; ${ }^{8}$ Division of Urology, Department of Surgery, Woodstock General Hospital, Woodstock, ON, Canada; ${ }^{9}$ Division of

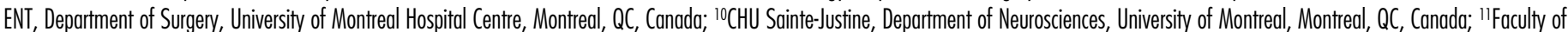
Medicine and the Division of Dermatology, University of Manitoba, Winnipeg, MB, Canada; ${ }^{12}$ Department of Ophthalmology, Faculty of Medicine, University of Manitoba, Winnipeg, MB, Canada; ${ }^{13}$ Kidney Cancer Research Network of Canada, Toronto, ON, Canada; ${ }^{14}$ Division of Urology, McGill University, Montreal, QC, Canada; ${ }^{15}$ Division of Urology, Departments of Surgical Oncology and Surgery, Princess Margaret Cancer Centre and the University Health Network, University of Toronto, Toronto, ON, Canada; ${ }^{16 S}$ Section of Urology, Department of Surgery, University of Manitoba, Winnipeg, MB, Canada

Cite as: Can Urol Assoc J 2016;10(7-8):E214-22. http://dx.doi.org/10.5489/cuaj.3798 Published online July 12, 2016

\section{Abstract}

Introduction: Optimal clinical assessment and subsequent followup of patients with or suspected of having a hereditary renal cell carcinoma syndrome (hRCC) is not standardized and practice varies widely. We propose protocols to optimize these processes in patients with hRCC to encourage a more uniform approach to management that can then be evaluated.

Methods: A review of the literature, including existing guidelines, was carried out for the years 1985-2015. Expert consensus was used to define recommendations for initial assessment and followup.

Results: Recommendations for newly diagnosed patients' assessment and optimal ages to initiate followup protocols for von Hippel Lindau disease (VHL), hereditary papillary renal cancer (HPRC), hereditary leiomyomatosis with renal cell carcinoma (HLRCC), Birt-Hogg-Dubé syndrome (BHD), familial paraganglioma-pheochromocytoma syndromes (PGL-PCC), and tuberous sclerosis (TSC) are proposed.

Conclusions: Our proposed consensus for structured assessment and followup is intended as a roadmap for the care of patients with hRCC to guide healthcare providers. Although the list of syndromes included is not exhaustive, the document serves as a starting point for future updates.

\section{Introduction}

The yearly incidence of renal cell carcinoma (RCC) in Canada is estimated to be 6000 cases; in the U.S., it is 61 $500 .^{1,2}$ Hereditary renal cell cancer syndromes (hRCC) are genetic disorders where the RCC phenotype is attributed to an inherited genetic mutation. hRCC currently appear to constitute $3-8 \%$ of all RCC. ${ }^{3-5}$ Many patients with renal tumours are not suspected of harbouring mutations and are managed as sporadic, non-hereditary cancers. ${ }^{6,7}$ Due to the rarity of these individual syndromes, recommendations for investigating the various manifestations of the syndrome(s), for the initial assessment, and for surveillance followup vary widely. ${ }^{8-11}$ In addition, a number of hRCC are multisystem disorders requiring input from a variety of specialists, which creates the need for a complex multidisciplinary network.

Early detection and preemptive therapeutic strategies for some hRCC may improve survival and maximize both organ preservation and quality of life. ${ }^{12}$ The challenge is to define the optimal and cost-effective protocols that maximize the detection of treatable conditions at an optimal stage while minimizing harm in an often young, otherwise healthy patient population.

We have proposed guidelines for identifying patients who should undergo genetic assessment for hRCC. ${ }^{13}$ In this report, we propose recommendations for the initial investigations and surveillance of patients with an established hRCC. We do not address treatment recommendations for these conditions. 
Although the characterization and grouping of hRCC is evolving, we have limited our recommendations to those hRCC in which renal tumours are a prominent clinical presentation and various recommendations are available, including: von Hippel Lindau syndrome ( $\mathrm{VHL}$ ), hereditary papillary renal cell carcinoma (HPRC), hereditary leiomyomatosis renal cell carcinoma (HLRCC), Birt-Hogg-Dubé syndrome (BHD), hereditary paragangliomas-pheochromocytoma syndromes (SDHB/SDHC/SDHD) and tuberous sclerosis complex (TSC). These are presented in Table 1 and each is associated with a specific histologic variant of RCC. A summary of each of the syndromes has been provided in our previous publication. ${ }^{13}$ Other hereditary cancer syndromes in which RCC is a minor component include Cowden syndrome and LiFraumeni syndrome, which have well-established clinical guidelines. ${ }^{14}$ This guideline will not address hereditary hyperparathyroidism-jaw tumour syndrome, papillary thyroid carcinoma with associated papillary RCC, constitutional chromosome 3 translocations, and BAP1-associated RCC. There is a paucity of data on these disorders; therefore, it is difficult to make any meaningful clinical recommendations at this time.

The objective of our proposed protocols is to optimize the processes in care of patients with hRCC to encourage a more uniform approach to management that can be evaluated. These protocols are proposed for patients who fulfill the diagnostic clinical criteria of hRCC or have a molecular genetic diagnosis of a hRCC through germline genetic testing. We hope this will enable a more standardized reporting, as well as knowledge transfer for those providers involved in the RCC aspect of these disorders. The surgical management of the renal tumours in these syndromes is beyond the scope of these guidelines.

\section{Methods}

A review of the English literature using a MEDLINE search from 1985-2015, with MESH terms that included renal cell carcinoma, kidney neoplasms, practice guidelines, and hereditary cancer syndromes was carried out. Text-word combinations included familial RCC, von Hippel-Lindau, hereditary papillary renal cancer, hereditary leiomyomatosis, hereditary paragangliomas and pheochromocytomas, Birt-Hogg-Dubé, and tuberous sclerosis complex. Additional relevant articles known to authors or found in references of included publications have also been referenced. Furthermore, we searched the National Cancer Institute website for recommendations on VHL and HLRCC management. When discrepancies were observed between published recommendations, we developed a consensus recommendation based on expert opinion.

\section{Results}

The recommended optimal workup and followup of patients with hRCC syndromes are presented in Table 1.

\section{Von Hippel-Lindau (VHL) syndrome}

There are no international consensus guidelines for the management of $\mathrm{VHL}$ and our recommendations are a composite of a number of available recommendations, including the National Cancer Institute ( $\mathrm{NCl})$, Danish Coordination Group for $\mathrm{VHL}$, and the North American VHL Alliance guidelines (Table 2), with final expert consensus from our group. ${ }^{9-11}$ The most conservative clinical recommendations were agreed upon with respect to the starting age of surveillance, as well as frequency (Table 1). The optimal management of patients with $\mathrm{VHL}$ is provided by a multidisciplinary approach due to multi-organ system involvement. Renal and extrarenal manifestations are listed in Table 2. Gene penetrance exceeds $90 \%$ by 60 years of age and almost $100 \%$ of the patients with the syndrome have a VHL mutation when mosaicism is not considered. ${ }^{15-18}$ Disease manifestations may appear in early infancy, hence the need for early screening in individuals who are suspected to have a diagnosis of VHL. Frameshift and mutations that severely affect folding of the VHL protein are thought to increase the risk of RCC in VHL patients; ${ }^{19,20}$ however, insufficient evidence exists to modify investigation and surveillance based on mutation alone. The estimated average age at diagnosis of symptomatic RCC is 40 ; this being said, screening for RCC should be started at a much younger age, as the occurrence of renal tumours in VHL patients has been reported as early as 16 years old. ${ }^{21,22}$ Renal lesion may still be detected de novo until age 65, necessitating screening until at least this age. ${ }^{23}$ Importantly, screening in the absence of symptoms has been reported to improve the survival of VHL patients to $100 \%$ compared to only $40 \%$ of those diagnosed because of symptoms. ${ }^{24}$ In asymptomatic individuals, we recommend annual abdominal ultrasonography starting at eight years of age, which is consistent with the $\mathrm{NCl}$ and the North American VHL Alliance guidelines, but with the addition of abdominal magnetic resonance imaging (MRI) every two years starting at age 15, not 18 years.

For the central nervous system (CNS), it has been reported that screening hemangioblastomas in asymptomatic individuals was not indicated since surgery was considered only in symptomatic subjects. However, recent screening data reveals that annual vs. biannual screening can reduce the rate of symptomatic CNS lesions from $7.2 \%$ to $2.7 \% .{ }^{15}$ Furthermore, patients with newly discovered lesions at screening actually have had subtle neurologic symptoms related to their lesions, which were initially not recognized. ${ }^{25}$ Surveillance brain and spine MRI should begin at age 11 and should be continued every 


\begin{tabular}{|c|c|c|c|c|c|c|}
\hline Syndromes & VHL & HPRC & HLRCC & $\mathrm{BHD}$ & PGL-PCC & TSC \\
\hline $\begin{array}{l}\text { Gene } \\
\text { affected }\end{array}$ & VHL & MET & $\mathrm{FH}$ & FLCN & SDHB, SDHC, SDHD & TSC1, TSC2 \\
\hline Renal & $\begin{array}{c}\text { ccRCC } \\
\frac{\text { US of abdomen }}{\text { Start: Age } 8} \\
\text { Freq: Once } \\
\frac{\text { CT or MRI of }}{\text { abdomen }} \\
\text { Start: Age } 15 \\
\text { Freq: Annual }\end{array}$ & $\begin{array}{l}\text { Papillary I RCC } \\
\text { CT or MRI of } \\
\text { abdomen } \\
\text { Start: Age } 18 . \\
\text { Freq: If baseline } \\
\text { imaging } \\
\text { normal, CT } \\
\text { scan of the } \\
\text { abdomen or } \\
\text { MRI at age } \\
30 \text { and then } \\
\text { biannually }\end{array}$ & $\begin{array}{l}\text { Papillary II RCC } \\
\begin{array}{l}\text { MRI of abdomen } \\
\text { Start: Age } 8 \\
\text { Freq: Once } \\
\text { US of abdomen } \\
\text { Start: Age } 12 \\
\text { Freq: Biannual } \\
\text { CT or MRI of } \\
\text { abdomen } \\
\text { Start: Age } 18 \\
\text { Freq: Annual }\end{array}\end{array}$ & $\begin{array}{c}\text { Oncocytic, } \\
\text { chromophobe RCC } \\
\text { CT or MRI of } \\
\text { abdomen } \\
\text { Start: Age 20 } \\
\text { Freq: Every 1-3 } \\
\text { years }\end{array}$ & $\begin{array}{l}\text { ccRCC } \\
\frac{\text { CT or MRI of }}{\text { abdomen }} \\
\text { Start: Age } 15 \\
\text { Freq: Annual }\end{array}$ & 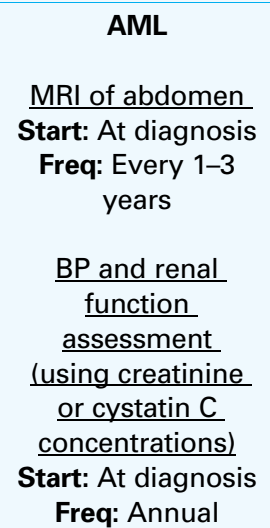 \\
\hline CNS & $\begin{array}{l}\text { Hemangioblastoma } \\
\frac{\text { MRI of brain and }}{\text { spine }} \\
\text { Start: Age } 11 \\
\text { Freq: } 1-2 \text { years }\end{array}$ & & & & & $\begin{array}{l}\text { SEN, SEGA, tubers, } \\
\text { seizures } \\
\text { MRI of brain } \\
\text { Start: At diagnosis } \\
\text { Freq: Every 1-3 } \\
\text { years } \\
\text { EEG } \\
\text { Start: At diagnosis } \\
\text { Freq: As clinically } \\
\text { indicated }\end{array}$ \\
\hline
\end{tabular}

$\begin{array}{lc}\begin{array}{l}\text { Neuro- } \\ \text { endocrine }\end{array} & \text { Pheochromocytoma } \\ & \begin{array}{c}\text { Plasma or urinary } \\ \text { metanephrines and }\end{array} \\ \frac{\text { cathecholamines }}{\text { Start: Age } 2} \\ \text { Freq: Annual }\end{array}$

\section{Pheochromocytoma paraganglioma}

Plasma or urinary metanephrines and cathecholamines and

US of abdomen

Start: Age 3

Freq: Annual

$\begin{array}{cc}\text { Eye } & \text { Retinal angiomas } \\ & \frac{\text { Dilated fundoscopy }}{\text { Start: Birth }} \\ \text { Freq: Annual }\end{array}$

Ear

\section{Endolymphatic sac} tumours

\section{Audiology testing \\ Start: Age 5-14 \\ Freq: Annual \\ MRI if recurrent \\ childhood ear infections}

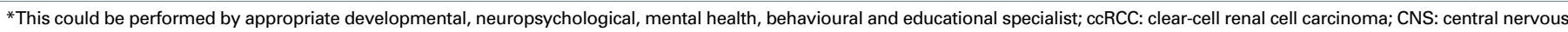

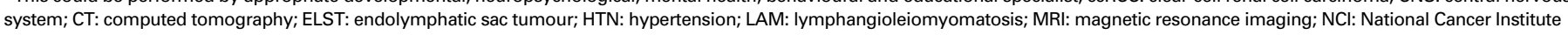

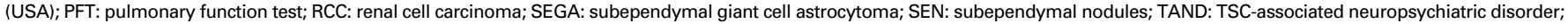
US: ultrasound; VHL: von Hippel Lindau.

1-2 years. A specialized VHL MRI protocol should be used on a 1.5T MRI with and without contrast with thin cuts through the posterior fossa and cervical-thoracic and lumbar spines.

For pheochromocytomas, the median age of diagnosis is 


\begin{tabular}{|c|c|c|c|c|c|c|}
\hline Syndromes & VHL & HPRC & HLRCC & $\mathrm{BHD}$ & PGL-PCC & TSC \\
\hline $\begin{array}{l}\text { Gastro- } \\
\text { intestinal }\end{array}$ & $\begin{array}{l}\text { Pancreatic cysts and } \\
\text { neuro-endocrine } \\
\text { pancreatic lesions } \\
\frac{\text { CT or MRI of }}{\text { abdomen }} \\
\text { Start: Age } 18 \\
\text { Freq: Annual }\end{array}$ & & & $\begin{array}{l}\text { Colonic neoplasia } \\
\text { Standard } \\
\text { population } \\
\text { screening } \\
\text { guidelines for } \\
\text { colon cancer }\end{array}$ & $\begin{array}{c}\begin{array}{c}\text { Gastrointestinal } \\
\text { stromal tumour } \\
\text { (GIST) }\end{array} \\
\text { MRI of abdomen vs. } \\
\text { endoscopy } \\
\text { Start: Shared } \\
\text { decision-making on } \\
\text { a case-by-case basis } \\
\text { given paucity of } \\
\text { information }\end{array}$ & \\
\hline $\begin{array}{l}\text { Gynecologic/ } \\
\text { genital }\end{array}$ & $\begin{array}{l}\text { Cystadenomas } \\
\text { of the epididymis } \\
\text { or broad uterine } \\
\text { ligament } \\
\text { No surveillance }\end{array}$ & & $\begin{array}{l}\text { Leiomyomas and } \\
\text { leiomyosarcomas } \\
\begin{array}{l}\text { Gynecologic } \\
\text { evaluation and US } \\
\text { of pelvis } \\
\text { Start: Age } 21 \\
\text { Freq: Annual }\end{array}\end{array}$ & & & \\
\hline Dermatologic & & & $\begin{array}{l}\text { Leiomyomas and } \\
\text { leiomyosarcomas } \\
\frac{\text { Dermatologic }}{\text { assessment }} \\
\text { Start: Age } 8 \\
\text { Freq: Annual }\end{array}$ & $\begin{array}{c}\text { Melanoma, } \\
\text { fibrofolliculomas } \\
\text { and other lesions } \\
\text { Dermatologic } \\
\text { assessment } \\
\text { Start: Diagnosis } \\
\text { Freq: Routine } \\
\text { followup not } \\
\text { recommended }\end{array}$ & & $\begin{array}{c}\begin{array}{c}\text { Angiofibromas } \\
\text { and other lesions }\end{array} \\
\begin{array}{c}\text { Dermatologic } \\
\frac{\text { assessment }}{\text { Start: At }} \\
\text { diagnosis } \\
\text { Freq: Annual }\end{array}\end{array}$ \\
\hline Respiratory & & & & $\begin{array}{c}\begin{array}{c}\text { Cystic lung } \\
\text { disease }\end{array} \\
\text { CT of chest } \\
\text { Start: At } \\
\text { diagnosis } \\
\text { Freq: As clinically } \\
\text { indicated }\end{array}$ & & $\begin{array}{c}\text { LAM } \\
\text { CT of chest and } \\
\text { PFT } \\
\text { Start: All adult } \\
\text { females or } \\
\text { symptomatic } \\
\text { patients } \\
\text { Freq: Every } \\
5-10 \text { years if } \\
\text { asymptomatic. } \\
\text { If cysts present, } \\
\text { preform annual } \\
\text { PFT }\end{array}$ \\
\hline Psychiatric & & & & & & $\begin{array}{c}\text { TAND } \\
\text { Clinical } \\
\text { monitoring* } \\
\text { Start: At } \\
\text { diagnosis } \\
\text { Freq: As clinically } \\
\text { indicated in } \\
\text { adulthood }\end{array}$ \\
\hline $\begin{array}{l}\text { This could be per } \\
\text { ystem; CT: comp } \\
\text { JSA); PFT: pulmo } \\
\text { S: ultrasound; Vr }\end{array}$ & $\begin{array}{l}\text { by appropriate developm } \\
\text { mography; ELST: endolym } \\
\text { inction test; RCC: renal cell } \\
\text { Hippel Lindau. }\end{array}$ & $\begin{array}{l}\text { Imo } \\
\text { SEG }\end{array}$ & $\begin{array}{l}\text { ntal health, behavioura } \\
\text { tension; LAM: lympha } \\
\text { mal giant cell astrocyt }\end{array}$ & $\begin{array}{l}\text { educational specialist; } \\
\text { iomyomatosis; MRI: } n \\
\text { EN: subependymal } n\end{array}$ & $\begin{array}{l}\text { C: clear-cell renal cell carcir } \\
\text { tic resonance imaging; NC } \\
\text {; TAND: TSC-associated }\end{array}$ & $\begin{array}{l}\text { a; CNS: central nervous } \\
\text { tional Cancer Institute } \\
\text { psychiatric disorder; }\end{array}$ \\
\hline
\end{tabular}

20 and these lesions appear before RCC or hemangioblastoma manifestations, but they have been reported as early as 2.5 years. ${ }^{25,26}$ Screening with yearly plasma-free metanephrines and 24-hour urinary catecholamines and metanephrines is widely available and is recommended starting at age two, which is consistent with the $\mathrm{NCl}$ recommendations. If biochemical abnormalities are detected, abdominal MRI or MIBG scans are indicated. The addition of abdominal crosssectional imaging (computed tomography [CT] or MRI) every two years at the age of 15 years is recommended even in the 
Table 1. Recommended assessment and followup of hereditary RCC syndromes (cont'd)

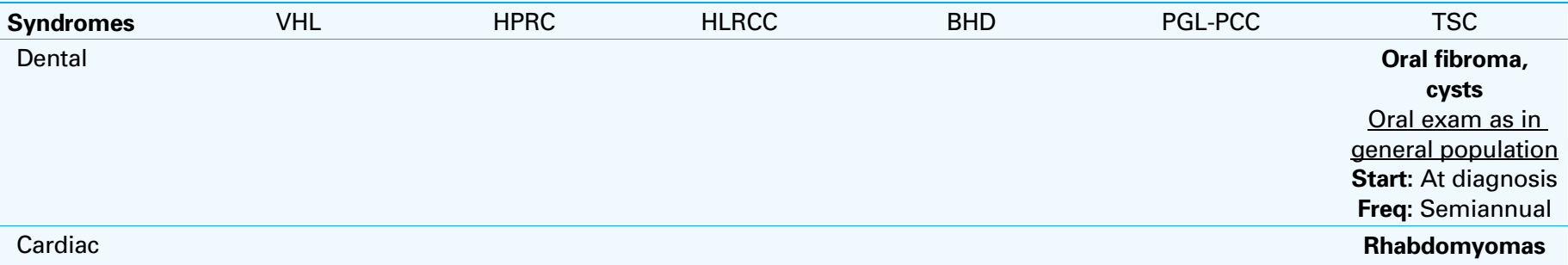

Echocardiogram

Start: Fetal, or in pediatric patients less than 3 years

ECG for conduction defects

Start: At any age

Freq: Every 3-5 years

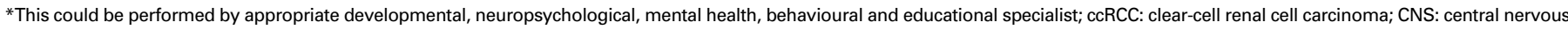

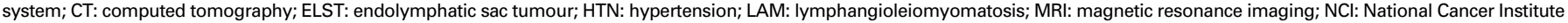

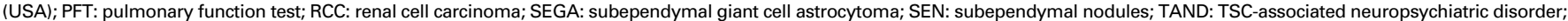
US: ultrasound; VHL: von Hippel Lindau.

Table 2. Existing guidelines for VHL disease screening and followup

\begin{tabular}{|c|c|c|c|}
\hline Organ system & $\mathrm{NCl}$ recommendations & VHL Alliance guidelines & Danish VHL guidelines \\
\hline \multirow[b]{2}{*}{ Kidney } & $\begin{array}{l}\text { US of abdomen } \\
\text { Start: Age } 8-18 \text { (earlier if indicated) } \\
\text { Freq: As clinically indicated }\end{array}$ & $\begin{array}{l}\text { US of abdomen } \\
\text { Start: Age } 8 \\
\text { Freq: Annual }\end{array}$ & $\begin{array}{l}\text { US of abdomen } \\
\text { Start: Age } 8-14 \\
\text { Freq: One baseline }\end{array}$ \\
\hline & $\begin{array}{c}\text { CT of abdomen } \pm \text { contrast (alternate with } \\
\underline{M R I)} \\
\text { Start: Age } 18 \\
\text { Freq: Annual }\end{array}$ & $\begin{array}{l}\frac{\text { MRI of abdomen }}{\text { Start: Age } 16} \\
\text { Freq: At least every second year }\end{array}$ & $\begin{array}{l}\text { US or MRI of abdomen } \\
\text { Start: Age } 15 \\
\text { Freq: Annual }\end{array}$ \\
\hline CNS & $\begin{array}{c}\text { Enhanced MRI of brain/spine. } \\
\text { Start: Age } 11 \\
\text { Freq: Every } 1-2 \text { years and if symptomatic }\end{array}$ & $\begin{array}{l}\text { Physical exam with neurological } \\
\text { assessment } \\
\text { Start: Age 1 } \\
\text { Freq: Annual } \\
\text { MRI of brain, cervical, thoracic and } \\
\text { lumbar spine } \\
\text { Start: Age } 16 \\
\text { Freq: Every } 2-3 \text { years }\end{array}$ & $\begin{array}{l}\text { MRI CNS } \\
\text { Start: Age } 8-14 \\
\text { Freq: One baseline, then } \\
\text { biannual starting age } 15\end{array}$ \\
\hline Eye & $\begin{array}{l}\frac{\text { Ophthalmoscopy }}{\text { Start: Birth }} \\
\text { Freq: Every 6-12 months }\end{array}$ & $\begin{array}{l}\text { Ophthalmoscopy } \\
\text { Start: Age } 1 \\
\text { Freq: Annual }\end{array}$ & $\begin{array}{l}\text { Dilated ophthalmoscopy } \\
\text { Start: Birth } \\
\text { Freq: Annual }\end{array}$ \\
\hline Neuro-endocrine & $\begin{array}{c}\text { Plasma or } 24 \text { hours urinary cathecholamines } \\
\frac{\text { and metanephrines }}{\text { Start: Age } 2} \\
\text { Freq: Annual and as clinically indicated if } \\
\text { HTN }\end{array}$ & $\begin{array}{c}\text { Plasma or urine fractionated } \\
\text { metanephrines and } \\
\text { normetanephrine } \\
\text { Start: Age } 5 \text { years } \\
\text { Freq: Annual } \\
\text { US of abdomen } \\
\text { Start: Age } 8 \text { or earlier if indicated } \\
\text { Freq: Annual }\end{array}$ & $\begin{array}{l}\frac{\text { Plasma-metanephrine and }}{\text { plasma normetanephrine }} \\
\text { Start: Age } 5 \text { years } \\
\text { Freq: Annual } \\
\text { Plasma chromogranin A } \\
\text { Start: Age } 15 \\
\text { Freq: Annual }\end{array}$ \\
\hline Ear & $\begin{array}{c}\text { MRI and CT of internal auditory canal. } \\
\text { Audiology and neurology assessments } \\
\text { Start: Any age for hearing loss, tinnitus, or } \\
\text { vertigo }\end{array}$ & $\begin{array}{c}\text { Audiology assessment } \\
\text { Start: Age } 5 \\
\text { Freq: Every } 2-3\end{array}$ & $\begin{array}{l}\text { Audiology assessment } \\
\text { Start: Age } 5 \\
\text { Freq: Annual }\end{array}$ \\
\hline
\end{tabular}

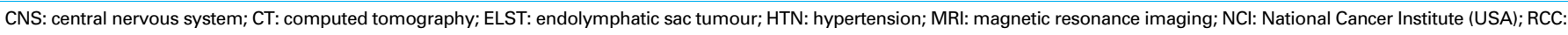
renal cell carcinoma; US: ultrasound; VHL: von Hippel Lindau. 
absence of biochemical evidence of pheochromocytomas, as up to $35 \%$ of $\mathrm{VHL}$-associated pheochromocytomas are non-functional. This imaging also overlaps with RCC surveillance in these patients.

The average age of occurrence of retinal angiomas (RA) is 21 years, with youngest case reported at age one. ${ }^{10,25}$ Successful treatment for RA requires minimal symptoms at the time of intervention. As with other lesions in VHL (e.g., RCC and pheochromocytoma), preemptive treatment produces superior outcomes when compared to delaying treatment until symptoms develop. ${ }^{10}$ This highlights the importance of annual ophthalmology assessment from birth or the time of VHL diagnosis, as outlined in the Danish and $\mathrm{NCl}$ recommendations. It is highly important for RA to be diagnosed presymptomatically for treatment to be successful.

Endolymphatic sac tumours (ELST) occur in $11-16 \%$ of VHL patients. ${ }^{27}$ Screening should be done yearly from ages 5-14 by audiological examination. Later in life, these exams can be done if tinnitus, hearing loss, or vestibular symptoms appear. In cases of recurrent childhood ear infections or when ELST is suspected, MRI of the temporal bone mastoid is indicated. ${ }^{28}$ If hearing loss occurs, it is usually irreversible.

The surveillance of pancreatic cysts, as well as that of neuroendocrine lesions of the pancreas, overlap with the screening and followup recommendations of RCC.

\section{Hereditary papillary renal cell carcinoma (HPRC)}

In HPRC, no extrarenal manifestations have been reported; hence screening is limited to the kidneys. Patients develop papillary type I RCC, which are hypovascular tumours leading to decreased detection on enhanced CT scanning due to a lack of enhancement. ${ }^{29}$ Ultrasound imaging may miss 55\% of the lesions detected on $\mathrm{CT}$, but is helpful to distinguish cystic from solid lesions. ${ }^{29} \mathrm{HPRC}$ tumours have a slow average growth rate of $0.19 \mathrm{~cm} /$ year, ${ }^{29}$ yet these tumours may become metastatic with mortality. ${ }^{30}$ Median age at diagnosis for RCC in patients with this condition has been reported initially to be in the sixth decade of life. ${ }^{31,32}$ However, more recent data revealed that early onset disease can occur, with a median of 43 years at first diagnosis. ${ }^{30}$ In this last study, the earliest diagnosis was made at age 19, although all the other patients in the cohort received their first diagnosis at age 30 and above.

Therefore we recommend at least a baseline enhanced MRI or CT scan of the abdomen at age 18 in patients at risk. If the initial assessment is negative, screening should be tailored to each case and risks discussed with the patient concerning the drawback of screening and the seemingly low risk of RCC in the third decade of life in HPRC patients. Screening can resume or be continued at age 30, when the risk of RCC is markedly increased, with an enhanced MRI or CT scan of the abdomen every two years. If there are established tumours identified, management will depend on the size and number of lesions.

\section{Hereditary leiomyomatosis renal cell carcinoma (HLRCC)}

A multidisciplinary approach to HLRCC is recommended, as the clinical manifestations include uterine leiomyomas with possibly a leiomyosarcomatous component and cutaneous leiomyomas, as summarized in Table 1. Papillary type II RCC is the predominant type of renal tumour associated with HLRCC; however, collecting duct carcinoma and tubulo-papillary carcinoma have also been reported. ${ }^{33}$ Renal tumours associated with HLRCC are considerably more aggressive than renal tumours in other hereditary tumour syndromes and benefit from early detection and aggressive treatment, often including surgical removal with regional lymphadenectomy. ${ }^{33,34}$ The diagnosis of renal cancer occurs predominately between the ages of 15 and 29, but has been shown to range from 5-48 years of age. . $3,34^{2}$ Estimated cumulative cancer risk in this disease is $15 \%$ and there is a relatively low risk of developing RCC before 20 years of age (about $1-2 \%$ ). ${ }^{34}$ Due to the rarity of this syndrome, surveillance should ideally be conducted at centres of expertise. A baseline abdominal MRI scan at the age of eight, followed by biannual abdominal ultrasounds has been proposed. ${ }^{34}$ However, the sensitivity of ultrasound has been questioned, given its limited ability to identify small lesions; therefore, when possible, annual MRI has been more recently recommended..$^{35}$ Also the so-called $3 \mathrm{~cm}$ rule (tumours can be safely monitored until they reach $3 \mathrm{~cm}$ before being resected) does not apply to HLRCC, as it does to other hereditary renal cancer syndromes. The aggressiveness of the renal manifestations implies that early screening and diagnosis, and aggressive surgical resection for even the smallest of renal lesions are strongly recommended. . $^{33,34}$ Papillary tumours often appear iso-echoic on ultrasound and can be missed if the tumour is small. It is thus important to obtain more sensitive baseline imagining, such as MRI. ${ }^{33}$ Recent groups recommend that affected individuals should be screened with annual cross-sectional imagining (preferably MRI to avoid ionizing radiation) starting at age $18 .{ }^{33,34}$ Abdominal imaging in children $<18$ years of age should be individualized and the pros and cons discussed with the patient, given the rare yet reported occurrence of renal tumour in the second decade of life. Annual MRI should be considered over ultrasound starting at the age of $18 . .^{34,36}$

Patients with HLRCC should also undergo annual skin examinations by a dermatologist from eight, due to associated cutaneous leiomyomas. The possibility that these lesions may have aggressive potential and behave as leiomyosarcomas is still under debate, but should be kept in mind when considering followup. The same logic applies for female patients, with annual gynecological examination 
starting age 21 and pelvic ultrasound due to the increased risk of uterine leiomyomas. ${ }^{35,37}$

\section{Birt-Hogg-Dubé (BHD)}

The clinical manifestations of BHD are summarized in Table I. Patients with BHD are at an increased risk of hybrid chromophobe-oncocytic, but also clear-cell carcinomas, chromophobe RCC, and oncocytomas. Patients typically develop renal tumours between 24 and 75 years of age. ${ }^{38-40}$ Consequently, we recommend patients with BHD should undergo cross-sectional imaging (CT or MRI) at least every 12-36 months in order to identify renal lesions starting at the age of $20 .^{39,40}$ Imaging with ultrasound is not recommended because hybrid chromophobe-oncocytic tumours often appear isoechoic to the renal parenchyma on ultrasound and may not be detected. ${ }^{40}$ While BHD-associated RCC is typically an indolent disease, patients often develop multifocal and bilateral lesions, which can progress to metastatic disease; therefore, regular surveillance is important for the appropriate management of these patients..$^{40}$

BHD is associated with lung cysts, which place patients at a higher risk of developing spontaneous pneumothoraces. It is recommended that patients undergo a CT scan of the chest at the time of diagnosis in order to identify any lung cysts; however, subsequent interval imagining is not recommended. ${ }^{38,40,41}$ Patients participating in at-risk activities for development of pneumothoraces (e.g., scuba diving) should undergo imaging of lungs at a younger age than $20 .{ }^{40}$ Patients may also develop associated skin manifestations, including cutaneous fibrofolliculomas, trichodiscomas, and perifollicular fibromas, and are potentially at risk of melanoma. ${ }^{42}$ Consequently, a formal dermatologic assessment should be conducted at diagnosis. However, melanoma surveillance is not recommended due to lack of evidence at this time. ${ }^{40}$ There may also be an association between $\mathrm{BHD}$ and colonic neoplasia; nonetheless, due to conflicting evidence, it is recommended that patients with BHD undergo the same colon cancer screening protocols as the general population. ${ }^{38}$

\section{Hereditary paraganglioma-pheochromocytoma syndrome (PGL-PCC)}

The clinical manifestations of PGL-PCC are associated with mutations in the SDH variety of genes. Clinical manifestations, in addition to paraganglioma and pheochromocytomas, include RCC and gastrointestinal stromal tumours (GIST), as summarized in Table 1. Of the six known PGLPCC genes, mutations in three genes - SDHB, SDHC, and SDHD - are associated with a propensity for $\mathrm{RCC}^{43}$ and we will limit our discussion to the management of patients with a mutation in these PGL-PCC genes. The median age of diagnosis for symptomatic RCC is 33 years, but has been shown to range from $15-62$ years of age. ${ }^{44}$ Early detection and intervention for renal tumours has been shown to improve clinical outcomes, as metastatic disease can develop from small primary tumour. ${ }^{44}$ Patients develop classic clear-cell RCC. ${ }^{44}$ Annual screening with abdominal imaging with MRI or CT scan is recommended starting at age 15 for the detection of both RCC and GIST tumours, and is done in concert with imaging screening for paraganglioma-pheochromocytomas. ${ }^{44-46}$

Paragangliomas and pheochromocytomas may manifest earlier than RCC and $20 \%$ of cases are diagnosed in the pediatric population, with the youngest case three years of age. ${ }^{45}$ Consequently, annual screening with plasma metanephrines and 24-hour urinary catecholamine and metanephrines is recommended three years of age. ${ }^{44-46}$ In addition, annual abdominal imaging is recommended, as up to $25 \%$ of paragangliomas and pheochromocytomas will have normal urine biochemistry. ${ }^{45}$ An expert opinion in endocrinology is encouraged.

The optimal imaging site and modality for PGL-PCC has not been established by the endocrine society and recent studies have shown the efficacy of whole body MRI. ${ }^{47,48}$ For the surveillance of RCC individuals harbouring an SDHB, SDHC, and SDHD mutation, we recommend MRI of the abdomen to be included in the surveillance protocol in conjunction with PGL-PCC biochemical screening. Radioisotope imaging can be added for diagnostic purposes. Given the paucity of data for GIST screening along with PGL-PCC, a shared decision-making process should be undertaken and screening individualized after discussing endoscopy and MRI.

\section{Tuberous sclerosis complex (ISC)}

As with VHL disease, the management of TSC should be carried out by a multidisciplinary team. The clinical manifestations of this entity are presented in Table 1. TSC complex is associated with benign angiomyolipomas (AMLs) of the kidneys that may grow significantly, causing renal dysfunction and more dramatically life-threatening hemorrhage. Renal cell carcinoma is associated with the TSC in $2-3 \%$ of patients. ${ }^{49}$ Extrarenal manifestations should not be overlooked when treating this condition. These are listed in Table 1.

The International Tuberous Sclerosis Complex Consensus Group, comprising 79 specialists from 14 different countries, has recently drafted recommendations for the initial screening and management of patients with TSC. ${ }^{50}$ The recommendations of our group fall in line with the recommendations made by this consensus group regarding screening. These are outlined in Table 1.

In summary, at diagnostic evaluation, abdominal imaging should be obtained, regardless of age. MRI is the recom- 
mended modality because it is more sensitive than ultrasound for the recognition of angiomyolipomas with minimal fat content and RCC. Both brain and abdominal MRIs can be done at the same time, especially for children who require sedation to undergo testing. In addition, blood pressure monitoring should be done, as well as blood work to calculate the glomerular filtration rate using creatinine equations or serum cystatin $\mathrm{C}$ concentration measurements.

For ongoing surveillance, MRI of the abdomen should be ordered every 1-3 years throughout the lifetime of the patient. This recommendation may be difficult to carry out in this patient population, with some patients requiring general anesthesia in order to undergo MRI imaging. In such cases, abdominal ultrasound may be considered a second best alternative. Assessment of the glomerular filtration rate and measurement of blood pressure should be done at least every year.

A dilated fundoscopy exam should be undertaken, starting with the time of diagnosis and annually thereafter in order to assess for achromic patches and retinal hamartomas. Likewise, a yearly dermatological assessment is recommended, starting at the diagnosis.

As outlined in Table 1, due to the association of TSC with pulmonary lymphangioleiomyomatosis (LAM), a baseline high-resolution CT scan of the lungs in with pulmonary function tests (PFT) are recommended in symptomatic males and all female patients older than 18 years. PFT can be repeated thereafter on a yearly basis.

Finally, cardiac rhabdomyomas, when present, usually occur in the young pediatric population and tend to involute with time. An echocardiogram should be obtained in patients under three years of age to assess for their presence and any associated heart failure. An electrocardiogram should be obtained at all ages of presentation to assess for conduction anomalies and repeated every 3-5 years on followup.

\section{Discussion}

Our proposed guidelines address the management of a variety of multisystem hereditary syndromes in which RCC is a common denominator. It provides a framework for RCC care providers to investigate and survey organ systems, including renal and non-renal manifestations. These recommendations collectively serve as a starting point for future validation. Our report does not address the cost-effectiveness of initial screening and followup. Given the demonstrated benefits of screening for other syndromes, it is reasonable to assume that benefits will be achieved in hRCC..$^{24,25,44,51}$ This will be addressed in future reports, when practice is harmonized among centres. Other future potential benefits of harmonization include enabling quality-of-care assessment and facilitation of knowledge transfer.
Given the clinical complexity in most of these rare syndromes, it cannot be overemphasized that a multidisciplinary approach should be the cornerstone of clinical management of affected patients and their families. The care delivery model of a "one-stop shop" clinic, where the various care providers are simultaneously present to provide their services is an option, but may not be practical in most settings. Alternatively, the use of patient navigators, virtual clinics, and/or telemedicine may provide the best alternatives in the future for these hereditary cancer populations. Whatever the mode of care, regular discussions at multidisciplinary panels by clinicians with expertise in hereditary RCC and associated syndromes should be undertaken, even for patients who need to be managed in community settings. The specific treatment of each case must individualized. Finally, surgical management of the renal tumours is beyond the scope of these guidelines.

\section{Conclusion}

Our recommendations propose a standardized pathway for the management of patients with hRCC. Its objective is to standardize practice for a very complex patient population, thus resulting in harmonization that will allow for care of individual patients to be optimized. Although the list of covered syndromes is not exhaustive, it serves as a starting point for future updates.

Competing interests: Dr. Lattouf has been an Advisory Board member for AbbVie, Amgen Astellas, Novartis, and Pfizer; and has received an educational grant from Janssen. Dr. Pautler has received grants from Intuitive Surgical. Dr. Reaume has been an Advisory Board member for GSK, Janssen, Novartis, Pfizer, and Sanofi; and has participated in clinical trials for Astellas, BI, BMS, Exelis, GSK, ImClone, and Synta. Dr. Green has been an Advisory Board member for and has received payment as a consultant from Novartis. Dr. So has been on Speakers' Bureaus for Amgen, Astellas, and Janssen. Dr. Major has recived payment as an invited speaker for Novartis and has participated in clinical trials for Novartis. Dr. Leicht has been an Advisory Board member for Bayer and Novartis; has received speaker fees from Alcon; has received grants/honoraria from Novartis; and has participated in clinical trials for Ophthotech. Dr. Basiuk has received honoraia as a speaker for Novartis and Pfizer. Dr. Tanguay has received grants/honoraria from Pfizer and Sanofi. Dr. Jewett has been an Advisory Board member for Novartis, Pfizer, and Theralase; has received honoraria from GSK, Novartis, and Pfizer; holds investments in Theralase; and has participated in cliical trials for GSK, Novartis, and Pfizer. The remaining authors declare no competing personal or financial interests.

This paper has been peer-reviewed.

\section{References}

1. Canadian Cancer Society. Canadian cancer statistics 2014. Available at: hittp://www.cancer.ca/ / media/cancer.ca/CW/cancer information/cancer 101/Canadian cancer statistics/Canadian-CancerStatistics-2014-EN.pdf. Accessed June 6, 2016.

2. American Cancer Society. Cancer facts \& figures 2015. Available at http://www.cancer.org/acs/groups/ content/@editorial/documents/document/acspc-044552.pdf. 2015. Accessed June 6, 2016. 
3. Shuch B, Vourganti S, Ricketts CJ, et al. Defining early-onset kidney cancer: Implications for germline and somatic mutation testing and clinical management. J Clin Oncol 2014;32:431-7. http://dx.doi. org/10.1200/JC0.2013.50.8192

4. Pavlovich CP, Schmidt $L S$. Searching for the hereditary causes of renal-cell carcinoma. Nat Rev Cancer 2004;4:381-93. http://dx.doi.org/10.1038/nrc1364

5. Linehan WM, Walther MM, Zbar B. The genetic basis of cancer of the kidney. J Urol 2003;170:2163-72. http://dx.doi.org/10.1097/01.ju.0000096060.92397.ed

6. Teh BT, Giraud S, Sari NF, et al. Familial non-VHL non-papillary clear-cell renal cancer. Lancet 1997;349:848-9. http://dx.doi.org/10.1016/S0140-6736(05)61751-5

7. Gudbjartsson T, Jonasdottir TJ, Thoroddsen A, et al. A population-based familial aggregation analysis indicates genetic contribution in a majority of renal cell carcinomas. Int J Cancer 2002;100:476-9. http://dx.doi.org/10.1002/iic. 10513

8. Bertelsen $M$, Kostelianetz M. An evaluation of the Danish national clinical guidelines for von Hippel-Lindau (VHL). Acta Neurochirurgica 2011;153:35-41;discussion. http://dx.doi.org/10.1007/s00701-0100786-3

9. Binderup ML, Bisgaard ML, Harbud V, et al. Von Hippel-Lindau disease (vHL). National clinical guideline for diagnosis and surveillance in Denmark. 3rd edition. Dan Med J 2013;60:B4763.

10. NiH National Cancer Institute. Genetics of kidney cancer (renal cell cancer) - Health professional version. Available at: http://www.cancer.gov/cancertopics/pdq/genetics/kidney/HealthProfessional/page2. Accessed June 6, 2016.

11. https://vhl.org/wp-content/uploads/2016/05/Surveillance-guidelines.pdf. Accessed June 6, 2016.

12. Lonser RR, Glenn GM, Walther M, et al. von Hippel-Lindau disease. Lancet 2003;361:2059-67. http:// dx.doi.org/10.1016/S0140-6736(03)13643-4

13. Reaume MN, Graham GE, Tomiak E, et al. Canadian guideline on genetic screening for hereditary renal cell cancers. Can Urol Assoc J 2013;7:319-23. http://dx.doi.org/10.5489/cuaj.1496

14. Daly MB, Pilarski R, Axilbund JE, et al. Genetic/familial high-risk assessment: Breast and ovarian, version 1.2014. J Natl Compr Canc Netw 2014;12:1326-38

15. Maher ER, Yates JR, Harries R, et al. Clinical features and natural history of von Hippel-Lindau disease. Q J Med 1990;77:1151-63. http://dx.doi.org/10.1093/qimed/77.2.1151

16. Maher ER, Webster AR, Richards FM, et al. Phenotypic expression in von Hippel-Lindau disease: Correlations with germline VHL gene mutations. J Med Genet 1996;33:328-32. http://dx.doi.org/10.1136/ img.33.4.328

17. Stolle $C$, Glenn $G$, Zbar B, et al. Improved detection of germline mutations in the von Hippel-lindau disease tumour suppressor gene. Hum Mutat 1998;12:417-23. http://dx.doi.org/10.1002/(SICI) 10981004(1998) 12:6<417::AID-HUMU8>3.0.C0;2-K

18. Crossey PA, Richards FM, Foster K, et al. Identification of intragenic mutations in the von Hippel-Lindau disease tumour suppressor gene and correlation with disease phenotype. Hum Mol Genet 1994;3:1303-8. http://dx.doi.org/10.1093/hmg/3.8.1303

19. Stebbins CE, Kaelin WG, Jr., Pavletich NP. Structure of the VHL-ElonginC-ElonginB complex: Implications for VHL tumour suppressor function. Science 1999;284:455-61. http://dx.doi.org/10.1126/science.284.5413.455

20. Nordstrom- $O^{\prime} B$ rien $M$, van der Luij $R B$, van Rooijen $E$, et al. Genetic analysis of von Hippel-Lindau disease Hum Mutat 2010;31:521-37. http://dx.doi.org/10.1002/humu.21219

21. Neumann HP, Bender BU, Berger DP, et al. Prevalence, morphology and biology of renal cell carcinomo in von Hippe-Lindau disease compared to sporadic renal cell carcinoma. J Urol 1998;160:1248-54. http://dx.doi.org/10.1016/S0022-5347(01)62509-6

22. Keeler LL 3rd, Klauber GT. Von Hippel-Lindau disease and renal cell carcinoma in a 16-year-old boy. J Urol 1992;147:1588-91

23. Maddock IR, Moran A, Maher ER, et al. A genetic register for von Hippel-Lindau disease. J Med Genet 1996;33:120-7. http://dx.doi.org/10.1136/jmg.33.2.120

24. Richards FM, Webster AR, McMahon R, et al. Molecular genetic analysis of von Hippel-Lindau disease. J Int Med 1998;243:527-33. http://dx.doi.org/10.1046/j.1365-2796.1998.00334.x

25. Poulsen ML, Budtz-Jorgensen E, Bisgaard ML. Surveillance in von Hippel-lindau disease (vHL). Clin Genet 2010;77:49-59. http://dx.doi.org/10.1111/i.1399-0004.2009.01281.x

26. Sovinz P, Urban C, Uhrig $S$, et al. Pheochromocytoma in a 2.75-year-old-girl with a germline von Hippel-Lindau mutation Q164R. Am J Med Genet A 2010;152A:1752-5. http://dx.doi.org/10.1002/ aimg.a.33407

27. Manski TJ, Heffner DK, Glenn GM, et al. Endolymphatic sac tumours. A source of morbid hearing loss in von Hippel-Lindau disease. JAMA 1997;277:1461-6. http://dx.doi.org/10.1001/ jama.1997.03540420057030

28. Poulsen ML, Gimsing $S$, Kosteljanetz $M$, et al. von Hippel-Lindau disease: Surveillance strategy for endolymphatic sac tumours. Genet Med 2011;13:1032-41. http://dx.doi.org/10.1097/ GIM.0b013e31822beabl
29. Choyke PL, Walther MM, Glenn GM, et al. Imaging features of hereditary papillary renal cancers. J Comput Assist Tomogr 1997;21:737-41. http://dx.doi.org/10.1097/00004728-199709000-00014

30. Schmidt LS, Nickerson ML, Angeloni D, et al. Early onset hereditary papillary renal carcinoma: Germline missense mutations in the tyrosine kinase domain of the met proto-oncogene. J Urol 2004; 172:1256-61. http://dx.doi.org/10.1097/01.ju.0000139583.63354.e0

31. Zbar B, Tory K, Merino M, et al. Hereditary papillary renal cell carcinoma. J Urol 1994;151:561-6.

32. Schmidt L, Junker K, Weirich $G$, et al. Two North American families with hereditary papillary renal carcinoma and identical novel mutations in the MET proto-oncogene. Cancer Res 1998;58:1719-22.

33. Alrashdi I, Levine S, Paterson J, et al. Hereditary leiomyomatosis and renal cell carcinoma: Very early diagnosis of renal cancer in a pediatric patient. Fam Cancer 2010;9:239-43. http://dx.doi.org/10.1007/ s10689-009-9306-0

34. van Spaendonck-Zwarts KY, Badeloe S, Oosting SF, al. Hereditary leiomyomatosis and renal cell cancer presenting as metastatic kidney cancer at 18 years of age: Implications for surveillance. Fam Cancer 2012;11:123-9. http://dx.doi.org/10.1007/s10689-011-9491-5

35. Pithukpakorn M, Toro JR. Hereditary leiomyomatosis and renal cell cancer 2010. Available from: http:// www.ncbi.nlm.nih.gov/books/NBK1252/. Accessed June 6, 2016.

36. Menko FH, Maher ER, Schmidt LS, et al. Hereditary leiomyomatosis and renal cell cancer (HLRCC): Renal cancer risk, surveillance, and treatment. Fam Cancer 2014;13:637-44. http://dx.doi.org/10.1007/ s10689-014-9735-2

37. Refae MA, Wong N, Patenaude F, et al. Hereditary leiomyomatosis and renal cell cancer: An unusual and aggressive form of hereditary renal carcinoma. Nat Clin Pract Oncol 2007;4:256-61. http://dx.doi. org/10.1038/ncponc0773

38. Lopez V, Jorda E, Monteagudo C. [Birt-Hogg-Dube syndrome: an update]. Actas Dermosifiliogr 2012;103:198-206. http://dx.doi.org/10.1016/i.adengl.2012.04.006

39. Menko FH, van Steensel MA, Giraud S, et al. Birt-Hogg-Dube syndrome: Diagnosis and management. Lancet Oncol 2009;10:1199-206. hittp://dx.doi.org/10.1016/S1470-2045(09)70188-3

40. Stamatakis L, Metwalli AR, Middelton LA, et al. Diagnosis and management of BHD-associated kidney cancer. Fam Cancer 2013;12:397-402. http://dx.doi.org/10.1007/s10689-013-9657-4

41. Toro JR, Pautler SE, Stewart L, et al. Lung cysts, spontaneous pneumothorax, and genetic associations in 89 families with Birt-Hogg-Dube syndrome. Am J Resp Crit Care Med 2007;175:1044-53. http:// dx.doi.org/10.1164/rccm.200610-14830C

42. Mota-Burgos A, Acosta EH, Marquez FV, et al. Birt-Hogg-Dube syndrome in a patient with melanoma and a novel mutation in the FCLN gene. Int J Dermato/ 2013;52:323-6. http://dx.doi.org/10.1111/i.13654632.2012.05742.x

43. Evenepoel L, Papathomas TG, Krol N, et al. Toward an improved definition of the genetic and tumour spectrum associated with SDH germ-line mutations. Genet Med 2015;17:610-2. http://dx.doi. org/10.1038/gim.2014.162

44. Ricketts CJ, Shuch B, Vocke CD, et al. Succinate dehydrogenase kidney cancer: An aggressive example of the Warburg effect in cancer. J Urol 2012;188:2063-71. http://dx.doi.org/10.1016/i.juro.2012.08.030

45. King KS, Prodanov T, Kantorovich V, et al. Metastatic pheochromocytoma/paraganglioma related to primary tumour development in childhood or adolescence: Significant link to SDHB mutations. I Clin Oncol 2011;29:4137-42. http://dx.doi.org/10.1200/JC0.2011.34.6353

46. Paik JY, Toon CW, Benn DE, et al. Renal carcinoma associated with succinate dehydrogenase B mutation: A new and unique subtype of renal carcinoma. J Clin Oncol 2014;32:e10-3. http://dx.doi.org/10.1200/ JC0.2012.47.2647

47. Lenders JW, Duh QY, Eisenhofer $G$, et al. Pheochromocytoma and paraganglioma: An endocrine society clinical practice guideline. J Clin Endocrinol Metab 2014;99:1915-42. http://dx.doi.org/10.1210/ ic.2014-1498

48. Jasperson KW, Kohlmann W, Gammon A, et al. Role of rapid sequence whole-body MRI screening in SDH-associated hereditary paraganglioma families. Fam Cancer 2014;13:257-65. http://dx.doi. org/10.1007/s10689-013-9639-6

49. Yang P, Cornejo KM, Sadow PM, et al. Renal cell carcinoma in tuberous sclerosis complex. Am I Surg Pathol 2014;38:895-909. http://dx.doi.org/10.1097/PAS.0000000000000237

50. Krueger DA, Northrup H, International Tuberous Sclerosis Complex Consensus G. Tuberous sclerosis complex surveillance and management: Recommendations of the 2012 International Tuberous Sclerosis Complex Consensus Conference. Ped Neurol 2013;49:255-65. http://dx.doi.org/10.1016/i.pediatrneurol.2013.08.002

51. Webster AR, Maher ER, Moore AT. Clinical characteristics of ocular angiomatosis in von Hippel-Lindau disease and correlation with germline mutation. Arch Ophthalmol 1999;1 17:371-8. http://dx.doi. org/10.1001/archopht.117.3.371

Correspondence: Dr. Jean-Baptiste Lattouf, Division of Urology, Department of Surgery, University of Montreal Hospital Centre, Montreal, QC, Canada; jean-baptiste.lattouf@umontreal.ca 